Универзитет у Нишу,

Филозофски факултет,

Департман за сочиологију, Ниш, Србија

DOI: https://doi.org/10.46630/gsoc.22.2019.06

\title{
СОЦИОЛОГИЈА ПОД ЛУПОМ ПОЛА РЕПСТАДА 2
}

Аутор надасве занимљиве књиге Шта је соииологија?루 Пол Репстад (Pål Steinar Repstad), рођен 1947, норвешки је социолог чија су поља интересовања социологија религије и квалитативне методе истраживања у друштвеним наукама ${ }^{4}$. Шта је социологија?, за разлику од других Репстадових књига, представља студију општег типа, у којој писац има интенцију да упозна читаоца са пољима које социологија истражује и истовремено укаже на њене могућности, истраживачке изазове и домете. Дефинисати социологију као најопштију науку о друштву није погрешно, сматра аутор, али није ни довољно. Не задовољавајући се оваквим општим одређењем, Репстад кроз пет поглавља ове књиге трага за нечим што је differentia specifica социологије у односу на друге области које истражују друштво.

Уобичајено је да се књиге које представљају увод у социологију пишу кроз опис и анализу њених теоријских праваца кроз историју или се, пак, баве рашчлањавањем друштва на његове сегменте, то јест подсистеме (културу, образовање, политику, економију, рад итд.), објашњавајући потом како социологија својим методама доприноси разоткривању постојећих механизама унутар истих. Репстад се, међутим, не држи строго ниједног од наведених приступа, те се може рећи да је ова студија нека врста релаксираног научног штива, што и јесте била његова интенција, како он сам тврди у предговору. Управо због тога се постиже да читалац без нарочитог напора, до самог краја књиге бива добро упознат са најзначајнијим именима социологије, социолошким правцима и методама. И то не само захваљујући Репстадовом врсном познавању социологије и њене генезе, већ пре свега једноставном, а истовремено прегнантном стилу писања којим се он издваја у односу на друге који су писали слична штива.

\footnotetext{
${ }^{1}$ jelena.bozilovic@filfak.ni.ac.rs

2 Пол Репстад, Шта је соииологија? КАРПОС, Лозница, 2019.

${ }^{3}$ Прво издање књиге Hva er sosiologi? објављено је 2007. године, у оквиру серије издања Шта je... (Hva er-bøkene, норвешке издавачке куће Universitetsforlaget) које је било инспирисано едицијом Very Short Introductions Oxford University Press-a.

${ }^{4}$ Поред више десетина чланака, (ко)аутор је и већег броја књига, од којих су неке: Политичка религија, свакодневна религија: социолошки трендови (Political Religion, Everyday Religion: Sociological Trends, 2019), Увод у соииологију религије (Innføring i religionssosiologi, у коауторству ca Inger Furseth, 2003), Бог на југу (Gud på Sørlandet, у коауторству са Anne Løvland \& Elise Seip Tønnessen, 2008), Дубоко, тихо, снажно, нежно. Религијска моћ у данашњој Норвешкој (Dype, stille, sterke, milde. Religiøs makt i dagens Norge, 2002), Између блискости и дистанце. Квалитативне методе у друштвеним наукама (Närhet och distans. Kvalitativa metoder $i$ samhällsvetenskap, 1999).
} 
Аутор књигу почиње описујући своје одрастање у Норвешкој педесетих година прошлог века, дајући обрисе индивидуалистичке друштвене и културне климе која је тада владала. Тиме уводна прича о социологији постаје субјективно обојена и “личнија" од традиционалних уџбеника. Присутна субјективност већ на самом почетку књиге ствара исправан осећај да ће књига бити растерећена уобичајене строгоће и систематичности каква се може очекивати од студија оваквог типа. Искуство живота у два различита места током одрастања побудило је интересовање да се одређене друштвене појаве боље разумеју, па нас аутор кроз причу о одрастању уводи у сопствену спознају о себи као „малом“" социологу. Дечачка социолошка имагинација развијала се кроз потребу да се разуме свет око себе, и то кроз компарацију начина живота у два града у којима се провело детињство. Управо то наводи Репстада на закључак да и социологија има извор у чуђењу, баш као и филозофија. Социологија се, међутим, раздваја од филозофије, јер је социолошко знање научно знање и као такво оно мора одговорити захтевима науке и уклопити се у научне постулате. Но, без обзира на научне стандарде, сазнања о друштву морају се саопштавати тако да буду разумљива, и то не само социолозима, већ свакоме ко се води здраворазумским промишљањем друштва. Репстад такав свој став и демонстрира у овој књизи, будући да и најкомпликованије теорије овде бивају јасне, што за исход има да и она читалачка публика која није у социолошкој струци сасвим добро може ући у причу и увидети на које је све начине могуће разумети тако апстрактну ствар као што је друштво.

Књига је подељена у пет поглавља: I Дефиниција социологије, II Социологија одозго, III Социологија одоздо, IV Повезивање људи и друштвених организација и V Социологија у друштву.

На почетку другог и уједно најобимнијег поглавља “Социологија одозго”, аутор појашњава своју класификацију социологије, истичући да она није истоветна подели на макросоциологију и микросоциологију, како би се могло помислити. Социологија одозго, по Репстаду, јесте она врста приступа који сагледава однос између људи (актера) и структура (система) фокусирајући се на печат који дате структуре остављају на људе (њихово делање и понашање), док социологија одоздо почива на проучавању интеракције међу људима, а потом испитујући како се ове релације утискују у структуре, одржавајући их или пак мењајући. Ову грубу типологију, односно конструкцију, аутор затим попуњава социолошким теоријама, полазећи од структуралног функционализма, марксизма и Веберових анализа, да би нам социологију одоздо (III поглавље) приближио кроз теорију рационалног избора, симболички интеракционизам и етнометодологију. Критички анализирајући дате теорије, Репстад наставља да упознаје читаоце са социологијом спуштајући се са теорија ка кључним социолошким појмовима, попут друштвене институције, друштвене улоге, друштвених норми, социјализације, стигматизације, девијације, друштвеног конфликта и других.

Репстад у претпоследњој глави књиге заузима критички приступ, при чему и домете теорија унутар социологије одозго и социологије одоздо схвата 
релативно и условно. Социологија одозго сувише се држи друштвене структуре, међутим, аутор сматра да структура није попут крутог скелета, нити она постоји одвојено од људских активности, па се без њих не треба сагледавати, нити може до краја разумети. Са друге стране, ограниченост социологије одоздо огледа се у томе што ни људско деловање никад није сасвим независно и аутономно, већ се увек одиграва унутар одређеног друштвено-институционалног поља које му одређује границе. Баш због тога је за проучавање друштва неопходно да социолог буде флексибилан и кадар да комбинује приступе у зависности од специфичности друштвеног проблема који жели истражити и објаснити. Ниједна социолошка теорија засебно није у могућности да пружи универзална научна објашњења за сваку друштвену појаву, јер се изнова појављују подручја друштвене стварности која измичу теоријским обрасцима. Међутим, управо на том месту „ускачу“ други теоријски приступи који на адекватнији начин могу пружити одговоре: „Није мудро да се одлучно заузимамо за једно становиште, а против другог. Друштвени живот је исувише богат и разноврстан да бисмо га могли описати само једним јединим моделом“ (стр. 195). То значи да разичите социолошке интерпретације немају универзалну моћ, већ само већу или мању експланаторну снагу у зависности од друштвеног поља које се истражује, што Репстад јасно кроз књигу илуструје примерима.

Последње поглавље бави се положајем социологије у друштву и њеним друштвеним ангажманом, при чему аутор износи извесну забринутост у погледу перспективе ове науке, која се тиче њеног уситњавања. Социологија, бивајући делом друштва, такође је подложна „ударцима“ глобалних друштвених трендова, а тренутно се развија и обликује по правилима и захтевима болоњског система образовања. Овај систем афирмише интердисциплинарност нудећи различите курсеве и стимулишући оријентисаност ка настави са темама. То само по себи има своје предности, будући да је свет интердисциплинарно устројен и треба му тако и приступити. Насупрот тематском приступу проучавања стоји шири, дисциплинарни приступ, који као такав омогућава критичкије и дубље сагледавање стварности, односно друштва. Он је, међутим, са специјализацијом унутар области науке и образовања потиснут и могао би нестати, што би имало негативне последице на дуже стазе, како по друштво, тако и по социологију Специјализација социолошке науке која је на делу, може бити корисна друштвеним институцијама којима су потребна истраживања ужих друштвених подручја и специфични социолошки увиди. Међутим, велико нагињање у овом развојном правцу може довести до тога да у будућности имамо „социологију без друштва“, како тврди Репстад. То значи да би ова наука радила за потребе служби админситрације или тржишта, чиме би се спонтано престало са критичким повезивањем делова друштвене стварности, чије понекад скривене споне откривају дубље системске пукотине или узроке одређених друштвених појава и проблема. Овакав развојни тренд социологије потврђују истраживања о радним местима социолога, где се констатује да се они у Норвешкој данас претежно баве административним послом, уместо планирањем друштва, што је некада био идеал социологије. 
У вези са тим, треба нагласити и да Репстад усваја Бергеров став да примарни задатак социологије није пракса, већ разумевање, и да базични императив социолога треба да буде научни интегритет. То међутим не значи да социолошка знања не треба да буду део политичких реформи. Напротив. Открића социолошких истраживања итекако могу бити имплементирана као део развојних државних политика, али социолог мора задржати дистанцу према политици, партијама и политичком ангажману како би сачувао свој научни интегритет и ауторитет. Са друге стране, сваки социолог је истовремено и морално људско биће са системом вредности којим сагледава свеукупну стварност. У том погледу, аутор каже да су нам поред социологије у животу потребни и други увиди: филозофски, морални, естетски, итд. Јер, како тврди: „Социологија може да каже нешто о свему, али не и све о нечему“ (стр. 216).

На самом крају књиге, Репстад подсећа да је социологија емпиријска наука и да то не смемо заборавити. Друштво је у сталном кретању, а социолози те промене морају пратити. Друштвена ангажованост и смеле изјаве великих социолога (попут Гиденса, Баумана, Бека или Хабермаса) у виду критика савременог друштва, добродошле су и побуђују пажњу, али некада су исувише одвојене од емиријског света и неутемељене. Прошло је доста година откако је неко од њих своје тврдње изнео на основу прикупљених података срачунатих у проценте, подсећа Репстад. Зато је важно изнова усвајати чињеницу да социологија мора остати наука, као и да се научна димензија потискује управо онда када се пласирају уопштене и сажете тврдње о карактеристикама савременог доба.

Свеукупни утисак је да је пред нама добро утемељен портрет социолошке науке. Текст књиге ослобођен је усиљених и оштрих класификација и „фиока“, а опет успешно прави дистинкције приликом представљања знаменитих аутора, теорија и метода. Управо та карактеристика студију чини другачијом, оригиналном и надахњујућом, што је препоручује за коришћење у настави социологије. Можда је највећа предност књиге баш у томе што се она обраћа и онима који нису социолози, те и таква читалачка публика на инспиративан начин добија прилику да се сусретне са социологијом и научи да посматра друштво кроз специфичну диоптрију ове науке. Напред реченом свакако треба додати и да квалитету књиге, поред осталог, доприноси и одличан превод Софије Биланџије са норвешког језика. 